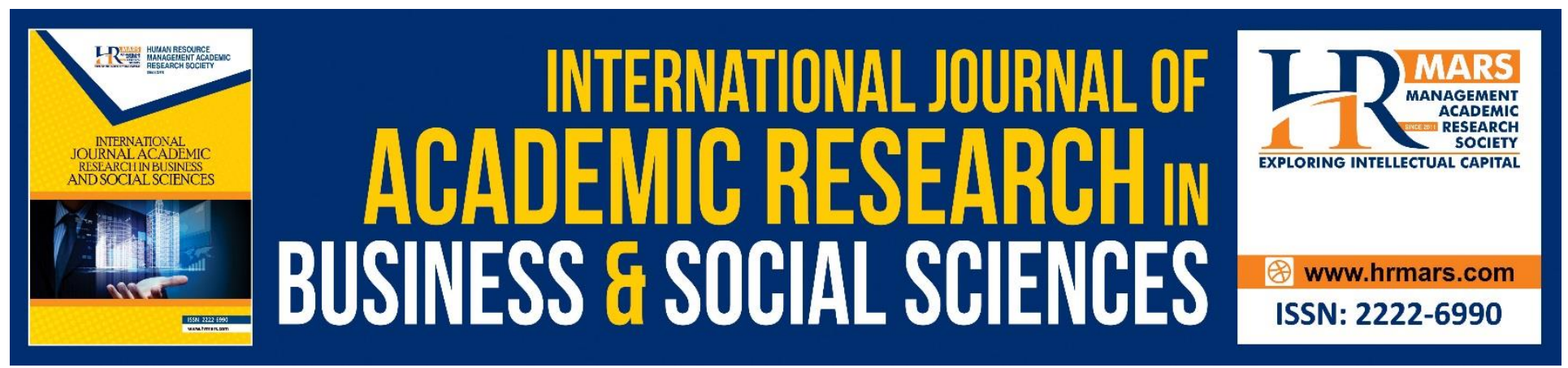

\title{
The Integration of Information and Communication Technology (ICT) in Teaching and Learning in Government and Private Preschools in Malaysia
}

\author{
Nordin Mamat, Kamarulzaman Kamarudin, Siti Rahaimah Ali \& Noraini \\ Mohamed Noh
}

To Link this Article: http://dx.doi.org/10.6007/IJARBSS/v10-i11/7881

DOI:10.6007/IJARBSS/v10-i11/7881

Received: 04 September 2020, Revised: 30 September 2020, Accepted: 17 October 2020

Published Online: 10 November 2020

In-Text Citation: (Mamat, Kamarudin, Ali, \& Noh, 2020)

To Cite this Article: Mamat, N., Kamarudin, K., Ali, S. R., \& Noh, N. M. (2020). The Integration of Information and Communication Technology (ICT) in Teaching and Learning in Government and Private Preschools in Malaysia. International Journal of Academic Research in Business and Social Sciences. 10(11), 104-112.

\section{Copyright: @ 2020 The Author(s)}

Published by Human Resource Management Academic Research Society (www.hrmars.com)

This article is published under the Creative Commons Attribution (CC BY 4.0) license. Anyone may reproduce, distribute, translate and create derivative works of this article (for both commercial and non-commercial purposes), subject to full attribution to the original publication and authors. The full terms of this license may be seen at: http://creativecommons.org/licences/by/4.0/legalcode

$$
\text { Vol. 10, No. 11, 2020, Pg. } 104 \text { - } 112
$$

Full Terms \& Conditions of access and use can be found at http://hrmars.com/index.php/pages/detail/publication-ethics 


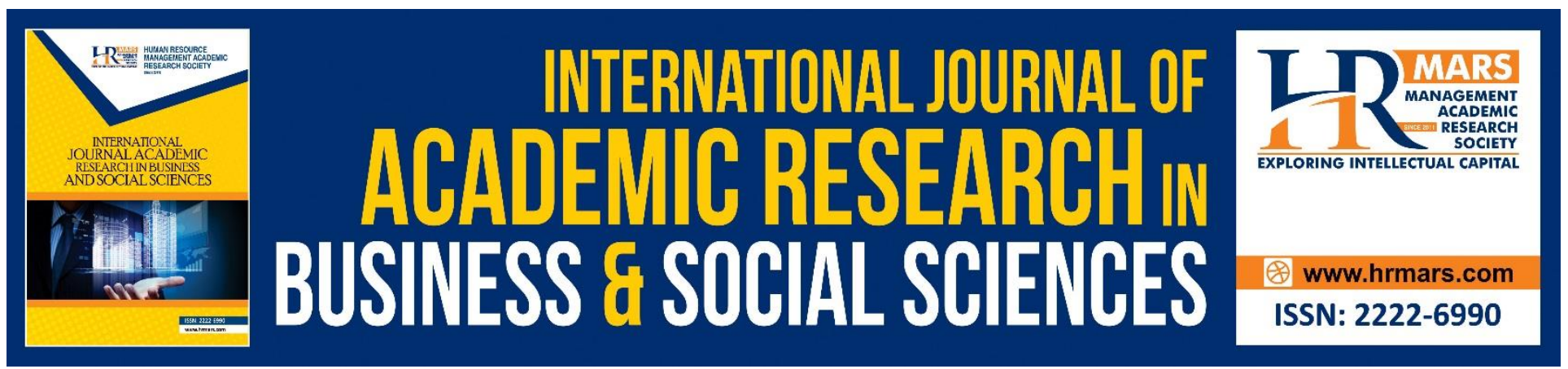

\title{
The Integration of Information and Communication Technology (ICT) in Teaching and Learning in Government and Private Preschools in Malaysia
}

\author{
Nordin Mamat, Kamarulzaman Kamarudin, Siti Rahaimah Ali \& \\ Noraini Mohamed Noh
}

Faculty of Human Development, Universiti Pendidikan Sultan Idris, Malaysia.

\begin{abstract}
This study aims to examine the differences in ICT integration in preschool teaching and learning between government and private sector. The three main aspects studied are the level of ICT knowledge and skills of preschool teachers, ICT integration in preschool teaching and learning and ICT problems faced by preschool teachers. The research method implemented is a quantitative study through data collection by distributing questionnaires to preschool teachers. The sample of this study consists of preschool teachers in Perak covering 311 schools involved. The data collected in this study were analyzed via computer using Statistical Packages for Social Sciences (SPSS) version 20.0. The findings show that the level of ICT knowledge and skills, the level of ICT integration in teaching and learning and the problems faced by preschool teachers are at a moderate level. However, the findings show that the government preschool teachers integrate ICT better in terms of monitoring and evaluating students' progress compared to private preschool teachers. In conclusion, based on the finding, the importance of ICT is accepted in our new generation. The demand of integrating technology into teaching since preschool will increase its importance in school curricula.
\end{abstract}

Keywords: ICT, Pre-school, Teaching, Children.

\section{Introduction}

This paper draws on a study which is part of a research project that surveys the differences in ICT integration in preschool teaching and learning between government and private. The Education Act of 1966 states that preschool education in Malaysia is an educational program for children aged between 4 years to 6 years old (Ministry of Education Malaysia, 2013). Realizing on the importance of education for these children, the government has opened up opportunities for parents to make a choice whether to send their children to public or private preschools (Yin, 2018). Three ministries have been given the responsibility to operate public preschools, namely the Ministry of Education, the Ministry of Rural and Regional Development, and the Department of National Unity (Mustafa \& Azman, 2013). Meanwhile, the establishment of private preschools (kindergartens) is to complement the government's efforts in providing quality education to these children. 
INTERNATIONAL JOURNAL OF ACADEMIC RESEARCH IN BUSINESS AND SOCIAL SCIENCES Vol. 10, No. 11, 2020, E-ISSN: 2222-6990 @ 2020 HRMARS

\section{Problem Statement and Literature Review}

The purpose of preschool education is to develop the potential of children as a whole, through fun, creative and meaningful environment and activities (Ministry of Education Malaysia, 2017). This is to improve skills and self-confidence with the current situation, abel to overcome challenges and carry responsibilities while in primary school later (Mohamed, et al., 2014). Preschool education is basic education to increase the potentials in children before entering the primary school environment. Nowadays, ICT is becoming increasingly important to be incorporated into teaching and learning process of preschool in the 21st century with the hope that Malaysian education is on par with education in other developed countries (Zakaria et al., 2017). The main question is, do preschool teachers have a sufficient level of knowledge and skills as well as readiness to perform this task.

Learning activities should be based on the needs, desires, abilities of the babies and children's background and development. Teachers should provide activities and organize teaching needs in the classroom to carry out learning activities (Mamat et al., 2017). In addition, educators or teachers also need to provide Information Communication Technology (ICT) tools such as computers. They also need to include portable mobile devices such as smartphones, game consoles, digital cameras, media players, netbooks, in-car satnav and handheld computers in teaching planning as well as the implementation of activities and learning, appropriate to the children's nursery and preschool level (Mamat et al., 2019; 2017; Traxler, 2010).

The integration of computers into broader early years sector, is not yet part of children's learning in the classroom (Parette et al., 2010) and very little research has taken place to examine the digital technologies that children under the age of five are using, hence there is limited evidence. Digital technology focus in this study are desktop, laptop, iPad, LCD player, digital cameras, VCD and netbook. Other than that, mobile devices including smartphones, game consoles, and media player. As well as audio visual transmission such as radio and television (Gillen \& Kucirkova, 2018).

Preschool teachers are aware that the use of ICT in preschool teaching and learning is one of the ways to increase the effectiveness of preschool teaching and learning. However, they face problems in integrating ICT in teaching and learning due to the lack of equipment such as LCDs and other multimedia components in schools (Rahman et al., 2013). Usually, these teachers cannot solve the problem if they want to know more about the use of an application. They often meet a dead end when that happens. This situation occurs because their peers in school have more or less the same level of competence as them.

The challenges of integrating ICT in the classroom is more to human-related challenges as opposed to overcoming technological challenges such as ICT equipment and facilities (Khamis \& Khalid, 2017). Basically, the challenge is not only related to helping teachers operate technological tools but also helping teachers acquire the knowledge and skills to integrate technology in their teaching. Therefore, the role of teachers also undergoes a transformation. Teachers play an important role in the classroom where teachers need to prepare challenging tasks and carry responsibilities. Teachers need to overcome various challenges, especially in terms of changing the role of teachers, teaching practices, mastery of ICT knowledge and skills (Puteh \& Salam, 2011). The success of the implementation of any changes and innovations in education are highly dependent on 
INTERNATIONAL JOURNAL OF ACADEMIC RESEARCH IN BUSINESS AND SOCIAL SCIENCES

Vol. 10, No. 11, 2020, E-ISSN: 2222-6990 @ 2020 HRMARS

the ability of teachers to refocus their roles and master new knowledge and skills, namely ICT skills, especially integrating them while implementing the teaching and learning process.

\section{Objectives}

The objectives of this study are to:

- examine the differences in ICT integration in preschool teaching and learning between government and private.

- study the level of ICT knowledge and skills among preschool teachers.

- examine the integration of ICT in teaching and learning among preschool teachers.

- examine the problems faced by preschool teachers in implementing ICT in preschool teaching and learning.

\section{Methodology}

This study is a survey study which uses the quantitative method. The collection of data was by distributing questionnaires to the government and private preschool teachers. The questionnaires given were on the use of ICT in preschool teaching and learning. The questionnaires consisted of four parts: Part A (Respondent profile information), Part B (Knowledge and skills level items), Part C (ICT integration items in teaching and learning) and part $D$ (Problem items faced by preschool teachers). This study was conducted on sample of studies consisting of preschool teachers in the state of Perak covering 311 preschools (Mamat et. al, 2018).

\section{Findings}

The findings of the study included three aspects, namely the level of knowledge and skills of preschool teachers, the integration of ICT in preschool teaching and learning and the problems faced by preschool teachers in using ICT. The findings of the study are shown in Table 1, Table 2 and Table 3.

Table 1: Level of Knowledge and Skills

\begin{tabular}{lll}
\hline & Mean Score \\
\cline { 2 - 3 } Equipment & Government & Private \\
\hline Interactive Smartboard & 1.35 & 1.35 \\
Projector & 2.15 & 1.18 \\
Television & 3.10 & 2.92 \\
Video & 2.32 & 1.36 \\
Digital Camera & 1.38 & 1.43 \\
Radio cassette recorder & 1.14 & 1.18 \\
Smartphone & 2.67 & 2.36 \\
Computer & 2.90 & 2.82 \\
Internet & 3.00 & 2.72 \\
\hline Total & 2.22 & 1.92 \\
\hline
\end{tabular}

\section{*1= Cannot afford, *2= Moderate, *3= Good, *4= Very Good}


INTERNATIONAL JOURNAL OF ACADEMIC RESEARCH IN BUSINESS AND SOCIAL SCIENCES Vol. 10, No. 11, 2020, E-ISSN: 2222-6990 @ 2020 HRMARS

Based on Table 1, data analysis found that government preschool teachers have better knowledge and skills in using projectors and smartphones than private preschool teachers. Mean scores indicated that the level of knowledge and skills of teachers in using projectors for government preschool teachers $(M=2.15)$ is at a moderate level compared to private preschool teachers $(M=1.18)$ which is at a low level. Meanwhile, the level of knowledge and skills in using smartphones for government preschool teachers $(M=2.67)$ is at a high level compared to private preschool teachers $(M=2.36)$ which is at a moderate level.

As for other aspects of knowledge and skills, data analysis found that government preschool teachers and private preschool teachers are at the same level i.e. preschool teachers show low levels in operating interactive whiteboards and radio cassette recorders. In addition, data analysis also showed that preschool teachers have a moderate level of knowledge and skills in using video and digital cameras. However, data analysis found that preschool teachers have a high level of knowledge and skills in using television, computers and the internet.

In conclusion, the overall data analysis from table 1 showed that the level of ICT knowledge and skills among government $(M=2.22)$ and private $(M=1.92)$ preschool teachers are at a moderate level.

Table 2: Integration of ICT in Teaching and learning

\begin{tabular}{|c|c|c|}
\hline \multirow[b]{2}{*}{ I use ICT for $\ldots$ learning in teaching and } & \multicolumn{2}{|c|}{ Mean Score } \\
\hline & Government & Private \\
\hline Provide teaching materials and reports & 3.11 & 2.68 \\
\hline $\begin{array}{l}\text { Using the internet to find teaching } \\
\text { materials }\end{array}$ & 3.25 & 2.71 \\
\hline Communicate with students and parents & 3.33 & 2.69 \\
\hline & 2.13 & 1.53 \\
\hline Control and evaluate student progress & & \\
\hline & 1.35 & 1.18 \\
\hline Make a presentation slide & 1.30 & 1.33 \\
\hline Provide online assignments & 1.15 & 1.19 \\
\hline Total & 2.23 & 1.90 \\
\hline
\end{tabular}

$* 1=$ Never,$* 2=$ Rarely, $* 3=$ Sometimes, $* 4$ = Always

Based on Table 2, data analysis found that government preschool teachers ( $M=1.35)$ use ICT better than teachers in private preschools $(M=1.18)$ for aspects of controlling and evaluating students' progress. The mean score showed government preschool teachers is at a moderate level compared to private preschool teachers which is at a low level.

Meanwhile, data analysis for other aspects of ICT integration indicated that government and private preschools have the same level of ICT integration. The data analysis showed that preschool teachers have a low level for aspects of making presentation slides and preparing online assignments. In addition, preschool teachers also showed a moderate level of aspects of building teaching aids with computers. However, data analysis showed that preschool teachers have a high level of ICT integration which is to use ICT in providing teaching materials, use the internet to find teaching materials and to communicate with students and parents. 
INTERNATIONAL JOURNAL OF ACADEMIC RESEARCH IN BUSINESS AND SOCIAL SCIENCES Vol. 10, No. 11, 2020, E-ISSN: 2222-6990 @ 2020 HRMARS

In conclusion, the overall data analysis from table 2 implied that the level of ICT integration in preschool teaching and learning among government preschool teachers $(M=2.23)$ and private preschool teachers $(M=1.90)$ are at a moderate level.

Table 3: Problems Faced by Preschool Teachers

\begin{tabular}{lll}
\hline \multicolumn{1}{c}{ Item } & \multicolumn{2}{c}{ Skor Min } \\
\cline { 2 - 3 } & $\begin{array}{l}\text { Keraja } \\
\text { an }\end{array}$ & Swasta \\
\hline $\begin{array}{l}\text { Problems with the technical support provided } \\
\quad \text { Time constraints using ICT in teaching and }\end{array}$ & 3.33 & 2.73 \\
$\begin{array}{l}\text { learning } \\
\quad \text { Lack of knowledge on how to use ICT }\end{array}$ & 3.68 & 2.69 \\
$\begin{array}{l}\text { equipment in teaching } \\
\quad \text { Weaknesses in choosing the appropriate } \\
\text { teaching approach to integrate ICT in teaching } \\
\quad \text { Lack of software or websites that support }\end{array}$ & 2.33 & 2.71 \\
$\begin{array}{l}\text { teaching and learning } \\
\text { Lack of ICT equipment in schools such as }\end{array}$ & $\mathbf{2 . 7 0}$ & 2.68 \\
computers & 1.20 & 1.17 \\
\hline$\quad$ Total & 2.15 & 1.19 \\
\hline
\end{tabular}

${ }^{*} 1$ = Strongly disagree, $* 2=$ Disagree, $* 3=$ Agree, $* 4=$ Strongly agree

Based on Table 3, data analysis reflected that government preschool teachers $(M=2.33)$ have less problems in terms of knowledge using ICT equipment in teaching which is at a moderate level, in contrast to private preschool teachers $(M=2.71)$ who have problems due to lack of knowledge in handling ICT equipment. However, as for the lack of ICT equipment in schools, the government preschool teachers indicated a mean score at a moderate level $(M=2.15)$ compared to the private preschool teachers $(M=1.19)$. Hence, this means that government schools are lack of ICT equipment compared to private schools.

In addition, there is a high mean score for both government and private preschool teachers as they experience problems with technical support, time constraints using ICT in teaching and weaknesses in choosing the appropriate approach in teaching. However, government and private preschool teachers have low level of mean score for lack of software or websites that support teaching and learning, this means that they are competent in using the software or websites.

In conclusion, the overall data analysis demonstrated that government $(M=2.57)$ and private $(M=2.20)$ preschool teachers have problems in using ICT at a moderate level.

\section{Discussion}

The findings of the study found that the level of ICT knowledge and skills among preschool teachers is at a moderate level. Data analysis showed that government preschool teachers have a better level of knowledge and skills in using projectors and smartphones than private preschool teachers. Teachers agreed that nurseries should prepare at least a computer. All teachers use digital technology especially TV and computers in teaching and activities. The use of technology helps a lot to keep kids' 
INTERNATIONAL JOURNAL OF ACADEMIC RESEARCH IN BUSINESS AND SOCIAL SCIENCES Vol. 10, No. 11, 2020, E-ISSN: 2222-6990 @ 2020 HRMARS

interested as a successful strategy. This finding supported by Gillen and Kucirkova (2018) and Arnott et al. (2019), where using ICT in early childhood education and the way the digital technology gives children's opportunity for richness in pedagogy and practice in early childhood education. It plays an important role in preschool to assist the development of children, especially in terms of language. The physical technology corner or space environment shapes children's daily life and experience (Marsh et al., 2019; Mamat et al., 2017).

In addition, the findings of the study also found that the level of ICT integration in teaching and learning among preschool teachers is at a moderate level. Data analysis reflected that government preschool teachers integrate ICT better in terms of monitoring and evaluating students' progress compared to private preschool teachers. Integration of digital technology in teaching and learning in preschool such as using the internet for youtube application. In order to expose the children to the IT world, the teachers agreed that the application of youtube is suitable since children are more familiar with it. Other activities included story telling and watching documentary. This finding supported by Zakaria et al. (2017) that the ICT is becoming increasingly important to be incorporated into the teaching and learning process of preschool in the 21st century.

Accordingly, the findings of the study also showed that the problems faced by preschool teachers are at a moderate level. Data analysis suggested that private preschool teachers have problems in terms of knowledge of operating ICT equipment compared to government preschool teachers, but private preschool teachers have less problems in terms of lack of ICT equipment in schools compared to government preschool teachers. This findings are in line with Rahman et al. (2013), and Khamis \& Khalid (2017); Darwish, Ahmed, \& Pahi, (2020) where preschool teachers face problems in integrating ICT in teaching and learning due to the lack of equipment and equipment in preschool centres.

\section{Conclusion}

In conclusion, based on the findings, the importance of ICT is accepted for our new generation. The impact of this research to theory gives a new input for teachers that the benefit of ICT integration in teaching and learning either from the government preschools or private preschools. The result from this study demonstrated the role of ICT in teaching and learning provides a real opportunity for teachers in preschool to rethink fundamental pedagogical approaches for children to apply in classrooms. Even though the level of ICT knowledge and skills among preschool teachers showed low to moderate but the demand of integrating technology into teaching since preschool will increase its importance in school curricula. The digital technology and innovative approaches need to be introduced to students at an early age before they are out-paced by constantly changing technology. By adopting a digital technology in pedagogical, teachers become strong proponents and advocates, as well as catalysts for educational innovation. Using YouTube, besides their entertainment value, have raised much attention in education and research because of their embedded advantages for learning. Although many educators are sceptical about digital technology such as YouTube, but entertaining activities can help children's development of cognitive skills, such as critical thinking, reasoning, and problem-solving skills. 
INTERNATIONAL JOURNAL OF ACADEMIC RESEARCH IN BUSINESS AND SOCIAL SCIENCES

Vol. 10, No. 11, 2020, E-ISSN: 2222-6990 @ 2020 HRMARS

\section{Acknowledgement}

This part of the research "Pengintegrasian Teknologi Maklumat dan Komunikasi (ICT) dalam Pengajaran dan Pembelajaran di Prasekolah Kerajaan dan Swasta" (2018-0229-107-01) is funded by the Universiti Pendidikan Sultan Idris, Malaysia for giving us the opportunity to carry out this research project.

\section{Corresponding Author}

Associate Prof. Dr. Nordin Mamat

Associate Professor

Department of Early Childhood Education

Faculty of Human Development

Universiti Pendidikan Sultan Idris

Perak Malaysia

Email:nordin@fpm.upsi.edu.my

\section{References}

Darwish, S., Ahmed, U., \& Pahi, M. H. (2020). Innovative work behavior during COVID-19 for medical representative in the pharmaceutical industry: Test of a moderation model in bahrain. International Journal of Pharmaceutical Research. 12(4), 19271934. doi.org/10.31838/ijpr/2020.12.04.277

Gillen, J., \& Kucirkova, N. (2018) Percolating spaces: Creative ways of using digital technologies to connect young children's school and home lives. British Journal of Educational Technology 49(5): 834-846.

Ministry of Education Malaysia. (2013). Akta Pendidikan 1966.

Ministry of Education Malaysia. (2017). Kurikulum Standard Prasekolah Kebangsaan.

Mustafa, L. M., \& Azman, M. N. A. (2013). Preschool education in Malaysia: Emerging trends and implications for the future. American Journal of Economics, 3(6), 347-351.

Marsh, J., Wood, E., \& Chesworth, L. (2019). Makerspaces in early childhood education: Principles of pedagogy and practice. Mind, Culture, and Activity 26(3), 221-233.

Mamat, N., Radzi, N. M. M., Luen, L. C., \& Yassin, S. M. (2017). The Selection of Meaningful Approach to Assess Children's Science Process Skills. International Journal of Academic Research in Business and Social Sciences. 7(4), 860-869. DOI:10.6007/IJARBSS/v7-i4/2897

Mamat, N., Luen, L. C., Radzi, N. M. M., Yassin, S. M., \& Yusoff, S. I. M. (2018). Reliability, Validity and Fairness of Interviews for Teaching and Learning Project in Quality Early Childhood Care and Education: Preliminary Study. International Journal of Academic Research in Business and Social Sciences. 8(6), 1283-1292. http://dx.doi.org/10.6007/IJARBSS/v8-i6/4516

Mamat, N., Luen, L. C., Mustapha, M. C., Razalli, A. R., \& Hashim, A. T. M. (2019). The Quality of PERPADUAN Pre-school Environment and Human Resources: Teachers' Satisfaction on their Career Development. International Journal of Academic Research in Business and Social Sciences. 9(5), 882-897. http://dx.doi.org/10.6007/IJARBSS/v9-i5/6015

Mohamed, N., Hassan, H., \& Hassan, M. N. Z. A. (2014).Tahap kesediaan pengintegrasian teknologi maklumat dan komunikasi (ICT) dalam pengajaran terhadap murid-pra murid sekolah: Satu tinjauan. Jurnal Penyelidikan TEMPAWAN, 31, 171-187. 
INTERNATIONAL JOURNAL OF ACADEMIC RESEARCH IN BUSINESS AND SOCIAL SCIENCES

Vol. 10, No. 11, 2020, E-ISSN: 2222-6990 @ 2020 HRMARS

Kamis, N., \& Khalid, F. (2017). Kekangan penggunaan teknologi maklumat dan komunikasi (TMK) dalam pengajaran dan pembelajaran guru prasekolah. Simposium Pendidikan diperibadikan: Perspektif Risalah An-Nur (SPRiN2017). 212-217.

Parette, H. A., Quesenberry, P., \& Blum, C. (2010) "Missing the Boat wit Technology Usage in Early Childhood Settings: a $21^{\text {st }}$ Century View of Developmentally Appropriate Practice." Early Childhood Education Journal 37, 335-343.

Puteh, S. N., \& Salam, K. A. A. (2011) Level of Readiness in Using ICT for Teaching and Its Effect on the Work and Behaviour of Preschool Pupils. Jurnal Pendidikan Malaysia, 36(1), 25-34.

Rahman, S., Nordin, A. B., \& Alias, N. (2013). Penggunaan ICT merentas Kurikulum Standard Prasekolah Kebangsaan (KSPK): Tinjauan di prasekolah Kementerian Pelajaran Malaysia. JuKu: Jurnal Kurikulum \& Pengajaran Asia Pasifik, 1(4), 12-20.

Traxler, J. (2010). "Will Student Devices Deliver Innovation, Inclusion and Transformation?" Journal of the Research Centre for Educational Technology 6 (1), 3-15.

Yin, T. H. (2018). Tahap kepuasan ibu bapa terhadap kualiti pendidikan prasekolah di Daerah Maran, Pahang. Jurnal Pendidikan Awal Kanak-Kanak, 7, 83-100.

Zakaria, S. R., Hamzah, M. I., \& Razak, K. A. (2017). Penggunaan ICT dalam pengajaran dan pembelajaran pensyarah pendidikan Islam di politeknik zon selatan. Tinta Artikulasi Membina Ummah, 3(1), 29-41. 